\title{
Competency Based-Learning and Quality Education in the New Normal Modality of Teaching
}

Leovigildo Lito D. Mallillin, Ph.D ${ }^{1 *}$, Regilito D. Laurel, Ph.D ${ }^{2}$, Jocelyn B. Mallillin, LPT 3 , Eduardo A. Carag, Ph.D. ${ }^{4}$, Catalina Guingab-CARAG ${ }^{5}$

${ }^{1}$ Consultant and Research Specialist

${ }^{2}$ Faculty of Education, English Department, University of Benghazi

${ }^{3}$ Master Teacher 1, San Bartolome High School

${ }^{4,5}$ Associate Professor V, Cagayan State University Philippines

Article History
Received: 27.01 .2021
Accepted: 30.03 .2021
Published: 03.04 .2021
Journal homepage:
https://www.easpublisher.com

Abstract: The global intensity of education continuously nurtures despite of the current pandemic in the new normal modality of teaching which highlights the competency development of education practice. It is imperative that competency based-learning is established through the initiative of the various educational institutions ability and capability. It needs to embrace the engrained opportunities in the curriculum learning design in the new normal and trends that utilize the innovative teaching and learning approaches to ensure competency based-learning and context development. The study examines competency based-learning and quality education that improves the modality of teaching in the new normal and addresses the competency based-learning programs according to the needs of students. The research employs the mixed method with integration of quantitative and qualitative research approach. It provides an opportunity evaluation of mixed methods to contribute in the practice and learning on the implementation of competency basedlearning in the new normal modality of teaching. It provides an outcome on achieving the effectiveness of the study. The subjects of the study are the professional teachers and lecturers in the various educational private and public institutions which include the private secondary schools, Department of Education (DepEd), and Commission on Higher Education Institutions (CHED). The study comprised 54 respondents only. The nonprobability purposive sampling is utilized in the study because it is straightforward and simple in identifying the sample population of the study. It is the most essential in matching the sampling set for the objectives and aims of the study. Results show that competency based-learning and programs are very flexible as to structure depending on the individual learners because students are guided in their learning process and control when and where they complete projects and assessments, students feel they can prove mastery, they can take an assessment, receive credit and start on their learning process, learners are empowered because they have control over when, where, and how they learn in their modules, it is free education for students to complete their subject and degree, and programs are focused and centered to the benefits of the learners in the new normal on real world competency development. Findings show that there is a significant difference in the improved competency based-learning and quality of education in the new normal modality of teaching as observed by the respondents.

Keywords: Competency based-learning, quality of education, modality of teaching, new normal online classes, flexibility learning, self-paced learning, affordable learning, skillsbased learning, and engagement learning.

Copyright (C) 2021 The Author(s): This is an open-access article distributed under the terms of the Creative Commons Attribution 4.0 International License (CC BY-NC 4.0) which permits unrestricted use, distribution, and reproduction in any medium for non-commercial use provided the original author and source are credited.

\section{INTRODUCTION}

Competency based-learning is essential in the quality of education especially during the new normal modality of teaching. This can be measured through the curriculum prescribed in the various educational institutions. It refers to the instruction system, grading, assessment, academic reporting, and performance of the students. It demonstrates the learning skills and knowledge expected in the progress of the learners. It determines the proficiency and competency of the subject area or given course as developed and standard in learning. Hence, competency based-learning has become the priority in the educational delivery system in the new normal modality of teaching. It provides training needs and experiences that transform the situation in the advancement of competency based- 
learning from the concept and theory to the new reality of teaching in the new normal, Goldhamer, Pusic, Co, $\&$ Weinstein [1]. Furthermore, competency basedlearning highlights the increase and importance of professional activities in an ideal educational system and curriculum. It assesses the enormous digital system and development to synthesize, integrate, and manage the learning process in the new normal and modality of teaching. It facilitates the system and assessment in real time feedback to enhance learning in the modality of teaching. It develops the platform of competency basedlearning to enhance lecturers in the burden of their teaching strategy. The function and competency basedlearning in the quality of education includes teacher learning portfolios, student feedback, e-books, assessment progress tracking, learning materials and analysis of the assessment for better improve modality of teaching in the new normal, Hsiao, Chou, Hsieh, Chang, \& Hsu [2].

On the other hand, the trend of competency based-learning and quality education in the new normal modality of teaching guides and assesses the student feedback on their academic performance in the skills that demonstrates their knowledge acquisition. It is a tool to evaluate and use learning in the various educational institutions. It is competency based-learning to relate its purpose, application, design, and criticism in the implementation of the practice evolution, trends, and benefits for the systematic process in the educational system. It is the process and design for the reflection toward the response to the related educational challenges especially during the new normal trends of teaching for contemporary demands in the competencybased learning integration of domain and student learning beyond authenticity, cognition, interdisciplinary characterize learning design feature and situation. It follows the progress of students in the literacy assessment and education preparation for competency based-learning demand. It determines and involves the necessity of the competency based-learning of students in the future, Gallardo [3]. Consequently, CBL evolves continuously for students to explore alternative learning in the new normal modality of teaching. It provides activities and policies in exploring the competency based-learning program. It highlights the instructional techniques, approaches, and strategies in modality of teaching in the modern trends for student learning. It supports and offers the educational enhancement of students in navigating their learning process. It explores the continued competency basedlearning in different sophisticated levels and benefits of students in the educational instruction of teaching, Anderson [4].

Consequently, the goals of competency based learning and quality education in the new normal modality of teaching are to empower the enhanced learning, and instructional feedback of the learners. It implements and investigates the feedback in online competency based-learning experiences. It is an approach in an organized learning activity to assist students in the achievement of the learners' competency and implementation, Wang, Tlili, Lehman, Lu, \& Huang [5]. In addition, competency based-learning in online teaching helps in the adoption of both students and teachers in the educational goals and achievement through interaction, flexibility, and accessibility. The educational technology indicates and evolves related to the advance technology of learning and technical consideration. It addresses the online educators on perspective pedagogy of online learning. It provides and attempts a method of effective online teaching to investigate the effects of competency based-learning online in the students' learning enhancement performance, learning readiness and self-direction. It involves intervention on competency based-learning online comprehensively, Tsai [6]. Moreover, competency based-learning involves the discussion and engagement of its activities and goals in a directed intervention of education that promotes and highlights the scope of CBL in the new normal modality of teaching in the improved teaching and learning outcome role in the educational system and curriculum. It develops the quality and improves development of CBL guided by various changes of learning and theories that describes the principles of competency based-learning on how it explores and contributes in the perspective of the new normal modality of teaching integration and information. It improves and seeks a continuous professional development outcome in the increased skills and knowledge in a changing behavior system and approach. The teaching approaches to competency based-learning and strategies are a potential and effective contribution of the learning outcome of students. It is a guide to set the competency of quality education systems and practice. It adheres to the system of the competency based-learning principles in the modality of teaching in the new normal. It integrates the system and outcomes in multiple techniques and methods in teaching performance and strategies, Sargeant, Wong, \& Campbell [7].

Furthermore, the application of competency based- learning in the new normal modality of teaching offers a range wide privilege in the simulation of $\mathrm{CBL}$ to practice the skills and complexity of various educational institutions to facilitate learning effectively and implementation. The different applications are based on the phases and development of skills and knowledge, Chernikova, et al., [8]. The mastery of competency based-learning and idea must be given emphasis and attention in teaching and in learning through the use of advanced technology in the lesson delivery which is integral in the competency attainment in the classroom practice and principles. It provides professional development and professional teachers for the need and use of different competency based- 
learning approaches to ensure that teachers in the classroom are prepared and engaged in their teaching process and to involve student's interaction in the learning process as to technology and content learning. The competency based-learning positions the detailed description and definition of learning and integrates suggestions and ways into the teaching process in the new normal. It outlines challenges and benefits of competency based-learning approaches in teaching and completes the process in the modality of teaching in the current trends and application of the current educational system, Egbert, \& Shahrokini [9].

\section{RESEARCH QUESTION}

1. How competency based-learning and quality education improves the modality of teaching in the new normal?

2. Is there a significant difference in the improved competency based-learning and quality of education in the new normal modality of teaching as observed by the respondents?

\section{HYPOTHESIS}

There is a significant difference in the improved competency based-learning and quality of education in the new normal modality of teaching as observed by the respondents.

\section{Theoretical Lens}

This study is anchored on the "Learning theory foundations of simulation-based mastery learning", McGaghie, \& Harris [10] as this theory deals on simulation mastery based learning foundation and intervention in education. It recognizes the comprehension of competency based learning foundation and theory which is essential for program development in various educational institutions. It follows and describes the importance of theory and learning foundation to direct and shape the competency based-learning in education. It conceptualizes the learning principles framework and theory associated with the contribution of social cognitive, constructivist, and behavioral practice and learning. It converges the theory learning framework in evaluating, conducting, and planning a competency based-learning program in the education profession. It illustrates the education and descriptions of the advanced basic competency based learning in the new normal modality of teaching. On the other hand, this theory is also known as selfdetermination where it focuses on competency basedlearning and motivational theory which is important in education in the new normal situation. It extensively applies to various schools as teachers' means and development of evidence based practice in teaching relevance to the psychological needs of autonomy and competency on the positive impact of the motivation of students to engage in the activities of the classroom online based learning. It is an effective and proven theory that suggestes the classroom online based behavior influences students' variables and engagement in the modality of learning and in teaching. It explores the scientific learning and engagement of students' outcomes in their learning process. It perceives the quality competence of student and teacher relationship in the interaction of learning since students are the center of learning where it observes the two way process of teaching and learning for better output of the competency based-learning in the new normal modality of teaching. Competency based-learning reveals the consistency of the quality of student and teacher relationship on the influence and perceived effectiveness and efficiency of teachers in supporting the competency based learning of student's engagement and activities, Wood [11].

\section{Concept of the Study}

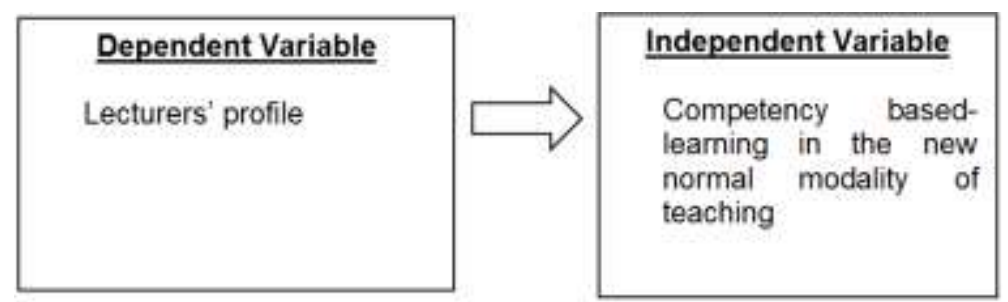

Fig-1: The dependent and independent variables on the competency based-learning in the new normal modality of teaching

\section{ReSEARCh Design}

The research employs the mixed method with integration of quantitative and qualitative research approach. It advances the emergent method of research in integrating the systematic or mixing of qualitative and quantitative data that sustains the investigation inquiry and program. It is a method of basic premise that permits the integration for the utilization and synergistic data of a separate analysis and collection of data in terms of quantitative and qualitative. It provides an opportunity evaluation of mixed methods to contribute in the practice and learning on the implementation of competency based-learning in the new normal modality of teaching. It provides an outcome on achieving the effectiveness of the study. It analyses and describes the perspective of the mixed method of research to summarize the various 
applications of education and learning modalities. It points out the shortcomings of the presentation and methods to support the agenda and development of the research under study. It reviews and tailors the diversity of the respondents' framework and sets forward the practices of quality results of the study. It is a collaborative educational setting applied in the research question of the study, Froehlich, Van Waes, \& Schäfer [12].

On the other hand, it is a contested debate on the knowledge and nature produce of qualitative research that will be judged legitimately according to the general set principles to assess the quality and concern manifested in the guidelines proliferation in judging the work quality in the field of education. It outlines the views on how the method of qualitative might be judged. It argues and assesses the research quality with reference to the broad criteria that attributes to the meaning and exact assessment for qualitative research guide, Mays, \& Pope [13].

Moreover, the quantitative method of research involves the sample required data collection of the indepth phenomenon and experiences on how the competency based-learning in the new normal modality of teaching is measured, Rahman [14].

\section{Participants of the Study}

The subjects of the study are the professional teachers and lecturers who are exposed to online teaching modality in the new normal where they are expert in the design of the competency based-learning among the learners. They are professional teachers in the various educational private and public institutions which include the private secondary schools, Department of Education (DepEd), and Commission on Higher Education Institutions (CHED). The study comprised 54 respondents only.

\section{Sampling Techniques}

Non-probability purposive sampling is utilized in the study because it is straightforward and simple in identifying the sample population of the study. It is the most essential in matching the sampling set for the objectives and aims of the study. It improves the rigor and trustworthiness of the results of the data in the different aspects of research and concepts as to confirmability, reliability, dependability and transferability of the study. It also outlines the intent and nature of non-probability purposive sampling in presenting the various applications and context of the study. It highlights the integration of purposive sampling as to dependent context and design of the study. It strategizes the sampling situation of the trustworthiness of the collection of data analysis situations. It is an approach selected in the use of purposive sampling that aligns the research objectives, aims, and methods in addressing such aspects. It explicits the approach made and used for sampling to improve the rigor method as judgement for the trustworthiness aspects of research, Klar, \& Leeper [15].

\section{Instrument Used}

\begin{tabular}{|c|c|c|}
\hline \multicolumn{3}{|c|}{ Competency based-learning and quality education } \\
\hline Scale & $\begin{array}{l}\text { Descriptive } \\
\text { Level }\end{array}$ & $\begin{array}{l}\text { Descriptive } \\
\text { Interpretation }\end{array}$ \\
\hline $4.20-5.00$ & Extremely Satisfied & $\begin{array}{l}\text { Competency based-learning and quality } \\
\text { education is Highly Observed }\end{array}$ \\
\hline $3.40-4.19$ & Very Satisfied & $\begin{array}{l}\text { Competency based-learning and quality } \\
\text { education is Observed }\end{array}$ \\
\hline $2.60-3.39$ & Neutral & $\begin{array}{l}\text { Competency based-learning and quality } \\
\text { education is Limited }\end{array}$ \\
\hline $1.80-2.59$ & Slightly Satisfied & $\begin{array}{l}\text { Competency based-learning and quality } \\
\text { education is Not Observed }\end{array}$ \\
\hline $1.00-1.79$ & $\begin{array}{l}\text { Not Satisfied } \\
\text { at All }\end{array}$ & $\begin{array}{l}\text { Competency based-learning and quality } \\
\text { education is Not observed at all }\end{array}$ \\
\hline
\end{tabular}




\section{RESULT}

Table-1: Competency based-learning and quality education improves the modality of teaching in the new normal

\begin{tabular}{|c|c|c|c|}
\hline Indicator & WM & I & $\mathbf{R}$ \\
\hline $\begin{array}{l}\text { 1. Competency based-program is a direct path to a successful career of student competency } \\
\text { graduates. }\end{array}$ & 3.89 & $\mathrm{~A}$ & 6 \\
\hline $\begin{array}{l}\text { 2. Students are able to complete a degree when they are ready with the use of technology } \\
\text { curriculum. }\end{array}$ & 3.93 & A & 3.5 \\
\hline $\begin{array}{l}\text { 3. Competency based program promotes individualized learning and accommodates a variety of } \\
\text { learning styles, making it a truly personalized experience. }\end{array}$ & 3.96 & $\mathrm{~A}$ & 1.5 \\
\hline $\begin{array}{l}\text { 4. It provides the learners progress in their module subjects through the materials provided in } \\
\text { the learning enhancement. }\end{array}$ & 3.89 & A & 6 \\
\hline $\begin{array}{l}\text { 5. Competency based-program is also flexible that allows students to enter a program at any } \\
\text { level where they are given credits. }\end{array}$ & 3.69 & $\mathrm{~A}$ & 17.5 \\
\hline $\begin{array}{l}\text { 6. The cost of competency based program varies by the different educational institutions } \\
\text { program and student pace. }\end{array}$ & 3.72 & $\mathrm{~A}$ & 15.5 \\
\hline $\begin{array}{l}\text { 7. Competency based-programs are very flexible as to structure depending on the individual } \\
\text { learners. }\end{array}$ & 3.85 & $\mathrm{~A}$ & 9 \\
\hline $\begin{array}{l}\text { 8. It is a skill based competency based program center that benefits the learners in the new } \\
\text { normal on real world competency development. }\end{array}$ & 3.80 & $\mathrm{~A}$ & 11 \\
\hline competency based education that increases student engagement in & 3.69 & $\mathrm{~A}$ & 17.5 \\
\hline $\begin{array}{l}\text { 10. Com } \\
\text { of st }\end{array}$ & 3.89 & A & 6 \\
\hline 11. Com & 3.93 & $\mathrm{~A}$ & 3.5 \\
\hline $\begin{array}{l}\text { 12. It is free educa } \\
\text { degree. }\end{array}$ & 3.85 & A & 9 \\
\hline ded in their learning and control when and wher & 3.78 & $\mathrm{~A}$ & 13 \\
\hline is that students are workplace ready and have expertise & 3.72 & $\mathrm{~A}$ & 15.5 \\
\hline owered because they have cont & 3.85 & $\mathrm{~A}$ & 9 \\
\hline $\begin{array}{l}\text { 16. It enables students to control their pacing because they are not confined by a set learning } \\
\text { process. }\end{array}$ & 3.78 & $\mathrm{~A}$ & 13 \\
\hline $\begin{array}{l}\text { 17. The school, college, or university created competency based programs precisely as a strategy } \\
\text { to increase learning. }\end{array}$ & 3.96 & A & 1.5 \\
\hline $\begin{array}{l}\text { 18. Students feel they can prove mastery, they can take an assessment, receive credit and start on } \\
\text { their learning process. }\end{array}$ & 3.61 & $\mathrm{~A}$ & 19.5 \\
\hline $\begin{array}{l}\text { 19. Programs are designed around competencies that are needed for a particular career ensuring } \\
\text { that materials provided in their modules are relevant. }\end{array}$ & 3.78 & $\mathrm{~A}$ & 13 \\
\hline $\begin{array}{l}\text { 20. Students are engaged in their module materials of teaching because they have ownership over } \\
\text { their learning. }\end{array}$ & 3.61 & $\mathrm{~A}$ & 19.5 \\
\hline Average We & 3.81 & $\mathrm{~A}$ & \\
\hline Standard Deviation & 0.109 & & \\
\hline
\end{tabular}

Table 1 presents the weighted mean and the corresponding interpretation on the competency basedlearning and quality education of teaching in the new normal.

It shows in the table that rank 1 is shared by the two indicators which are "Competency based program promotes individualized learning and accommodates a variety of learning styles, making it a truly personalized experience", and "The school, college, or university created competency based programs precisely as a strategy to increase learning", with a weighted mean of 3.96 or Agree which means the competency based-learning and quality education is "Observed". Rank 2 is also shared by the two indicators which are "Students are able to complete a degree when they are ready with the use of technology curriculum", and "Competency based-program of learning follows the educational policy in the new normal classes", with a weighted mean of 3.93 or Agree, which stressed that competency based-learning and quality of education is "Observed". Rank 3 is shared by the three indicators which are "Competency based-program is a direct path to a successful career of student competency 
graduates", It provides the learners progress in their module subjects through the materials provided in their learning enhancement", and Competency basedlearning of education focuses on final outcome of the learning process of students in the new normal classes", with weighted mean of 3.89 or Agree which emphasized that competency based-learning and quality education is "Observed". The least in rank is shared also by the indicators which are "Student feels they can prove mastery, they can take an assessment, receive credit and start on their learning process", and "Students are engaged in their module materials of teaching because they have ownership over their learning", with a weighted mean of 3.61 or Agree. The overall average weighted mean is 3.81 or Agree which means competency based-learning and quality education is "Observed" in the new normal perspective of learning among students.

Table-2: Significant difference on the improve competency based-learning and quality of education in the new normal modality of teaching as observed by the respondents

\begin{tabular}{|l|c|c|c|c|}
\hline & zcomputed value & comparison & z critical value & decision \\
\hline $\begin{array}{l}\text { Competency based-learning as } \\
\text { observed by the respondents }\end{array}$ & 256.86 & $>$ & \pm 1.96 & Rejected \\
\hline \multicolumn{4}{|c|}{ Two tailed test with 0.05 level of significance } \\
\hline
\end{tabular}

Table 2 presents the significant difference on the competency based-learning and quality of education that improves the modality of teaching in the new normal as observed by the respondents.

It reveals that the $\mathrm{z}$ computed value is greater than the $\mathrm{z}$ critical value which means the decision is rejected on the competency based-learning as observed by the respondents with 0.05 level of significance. Therefore, there is strong evidence that there is a significant difference in competency based-learning and quality of education improves the modality of teaching in the new normal as observed by the respondents. Hence, the alternative hypothesis is accepted.

Table-3: Thematic analysis and core idea on the competency based-learning and quality of education in Science subject curriculum of the new normal modality of teaching

\begin{tabular}{|c|c|c|c|}
\hline Theme & Frequency of Response & & \multicolumn{1}{c|}{ Core Idea } \\
\hline Flexibility & General & $\square$ & flexible program \\
& General & $\square$ & policy in the new normal classes \\
& Typical & $\square$ & guided learning control on assessment \\
& General & $\square$ & program credits \\
\hline Self-pace & Variant & $\square$ & learning outcome focus \\
& General & $\square$ & confine and control learning process \\
& Typical & $\square$ & mastery assessment of learning process \\
& Typical & $\square$ & degree of subject technology curriculum \\
\hline Engagement & Variant & $\square$ & student engagement in subject curriculum \\
& General & $\square$ & teaching ownership in learning \\
& General & $\square$ & empower learning process \\
& Typical & $\square$ & variety of learning style \\
\hline Affordability & Variant & $\square$ & cost of competency based program \\
& Variant & $\square$ & strategy in learning \\
& General & $\square$ & competency of subject and degree \\
& Typical & $\square$ & Enhancement of learning materials. \\
\hline Skills-based & General & $\square$ & learners development and competency \\
& General & $\square$ & program design and materials \\
& General & $\square$ & outcome workplace \\
& Typical & $\square$ & success of career path \\
\hline
\end{tabular}

\section{Flexibility}

Arguably resource flexibility and operational concept provides the demands in facing the benefits to establish the facilities and flexibility of learning to increase profitability. It quantifies the flexibility and benefits that can underestimate the true value of the demand of desired learning, Chod, Markakis, \& Trichakis [39]. Generally, the participants say that:
"Competency based-programs are very flexible as to structure depending on the individual learners". (T1-P28, P7)

"Competency based-program of learning follows the educational policy in the new normal classes". (T1-P27, P12)

"Students are guided in their learning and control when and where they complete projects and assessments". (T1-P28, P14) 
"Competency based-program is also flexible that allows students to enter a program at any level where they are given credits". (T1-P27, P12)

\section{Self-paced}

The self-paced domains and training affects the state of the art detectors and objects applied to various domains of learning. It alleviates the issues of the different methods and adaptations to improve the educational setting of learning. It transforms the learning self-paced in an efficient and smart way. It simplifies the effectiveness of the inference of learning in the new normal perspective. It demonstrates the performance utility of every framework and component of learning applicable in the measure and performance of the learners, Soviany, Ionescu, Rota, \& Sebe, [16]. Typically, the participants emphasized that:

"Competency based-Learning of education focuses on the final outcome of the learning process of students in the new normal classes". (T2-P26,P8)

"It enables students to control their pacing because they are not confined by a set learning process". (T2-P25, P9)

"Students feel they can prove mastery, they can take an assessment, receive credit and start on the learning process". (T2-P29, P11)

"Students are able to complete a degree when they are ready with the use of technology curriculum". (T2-P28,P9)

\section{Engagement}

Engagement on development opportunity and professional training assists the educational institutions to implement and expand the competencies in quality education practices in academics that engage in the extent of learning opportunity and gain of learning. It involves the various theories and explanations in achievement goals and motivations. It measures the learning intensity, effort, elaboration, risk-taking, persistence and implementation. Learning approaches engagement goals leads to functional learning. It analyses the amount of learning and academic achievement of the learners' quality experiences, Daumiller, Rinas, Olden, \& Dresel [17]. Generally, the participants observed that:

"It is a strongest outcome competency based education that increases student engagement in their subject". (T3-P31, P6)

"Students are engaged in their module materials of teaching because they have ownership over their learning". (T3-P30, P11)

"They are empowered because they have control over when, where and how they learn in their modules". (T3-P32, P11)
"Competency based program promotes individualized learning and accommodates a variety of learning styles, making it a truly personalized experience". (T3-P23,P13)

\section{Affordability}

Affordability challenges and illustrated the scale of technology learning in the new normal. It accelerates the instructional experiences, the equity of learning to cost and accessibility. It develops the essential and compelling stability of the technology in learning resources to support the lecturers to guide and create a meaningful engagement learning to pursue opportunities for accessible, affordable and effective in the various educational institutions, Gazi, Baker, \& Sibley, [18]. Variantly, the participants stressed that:

"The cost of competency based program varies by the different educational institutions program and student pace”. (T4-P29, P9)

"The school, college, or university created competency based programs precisely as a strategy to increase learning”. (T4-P29, P8)

"It is free education competency based learning for students to complete their subject and degree”. (T4-P34, P9)

"It provides the learners progress in their module subjects through the materials provided in their learning enhancement". (T4P26, P11)

\section{Skills-based}

Skills-based learning is increasingly dependent on lifelong learning that will rely on the era of sharing information to facilitate movement in the educational institutions. It helps in the prior recognition of learning to personalize the experience of learning. It utilizes the skills-based learning and curriculum that explores the analysis of the facilitation and process of learning, Kitto, et al., [19]. Generally, the participants say that:

"It is a skill based competency based program center that benefits the learners in the new normal on real world competency development". (T5-P29, P11)

"Programs are designed around competencies that are needed for a particular career ensuring that materials provided in their modules are relevant". (T5-P27,P5)

"Competency based-program outcome is that students are workplace ready and have expertise in their chosen fields". (T5-P27,P9)

"Competency based-program is a direct path to a successful career of students competency graduates". (T5-P26,P8) 


\section{DISCUSSION}

The global intensity of education continuously nurtures despite of the current pandemic in the new normal modality of teaching which highlights the competency development of education practice. It is imperative that competency based-learning is established through the initiative of the various educational institutions ability and capability. It needs to embrace the engrained opportunities in the curriculum learning design in the new normal trends that utilize the innovative teaching and learning approaches to ensure competency based-learning and context development, Markey, \& Okantey [20].

Furthermore, flexibility in the new normal modality of teaching reveals that competency basedlearning programs are structured depending on the individual learners on quality education. It increases the program development of CBLconcept and model in the various educational institutions to analyze the challenges and strategies in the implementation of the new normal modality of teaching to include alignment of traditional program, important loop feedback for quality standard of teaching, lecturers' interaction, student characteristics, flexibility interaction, and structure decision, Dragoo, \& Barrows, [21]. Hence, it reveals also that competency based-programming follows the educational policy in the new normal classes where education is a continuous process among the learners. It analyses the online process of learning and framework. It establishes a strategy and develops teaching support that focuses on the learning process of students' delivery mode of teaching and instruction in the new modality of online classes, Mallillin, Mallillin, Carag, Collado, \& Largo [22]. Besides, it reveals that students are guided in their learning and control when and where they complete projects and assessments to where it recognizes the competency based-learning, opportunity, development in various challenges, and pedagogy among students, O'Neill, et al., [23]. In addition, it reveals that competency based-program is also flexible that allows students to enter a program at any level where they are given credits. This includes the new modality of teaching in the new normal online teaching as a transition to educational setting and practices, Anderson [4].

Consequently, self-paced in quality education shows that competency based-learning of education focuses on the final outcome of the learning process of students in the new normal classes to emphasize on the knowledge integration in online learning to be introduced in the modality of teaching through integration of advance technology that contributes on the focused of the student learning enhancement, Mallillin, Carag, Mallillin, \& Laurel, [23]. It enables students to control their pacing because they are not confined by a set learning process to examine the response system in the educational setting on the student focused experience. It helps in the connection of the technological limits and benefits, instant feedback, questioning, anonymity, interaction, and engagement. It reveals student learning and complexity experience in the current understanding that contributes to the framework that offers a condition in the pedagogical implementation of learning and designs in competency based-learning, Wood, \& Shirazi [24]. Students also feel they can prove mastery; they can take an assessment, receive credit and start on the learning process. It reduces the learning process and the ability of teachers to observe the learning behavior and support students in the new normal modality teaching through the use of organized strategy, flexible effort, and time in the preferred online learning. It provides tips for the support of teachers in the new normal modality of teaching, Vanslambrouck, Zhu, Pynoo, Thomas, Lombaerts, \& Tondeur, [25]. Therefore, students are able to complete a degree when they are ready with the use of technology curriculum because it introduces the need of the various tools and technology in the quality of teaching and collaborative learning that explores in the academic course and pedagogical design in literacy digital competency of learning and outcome in the adoption of the learning innovation and instructional design in the modality of teaching, Blau, Shamir-Inbal, \& Avdiel [26].

Moreover, engagement on competency basedlearning and quality education shows that the strongest outcome competency based education that increases student engagement in their subject. It predicts the gain learning and decision of students based on engaged and identified practices as to course experiences, level course taught, and area of teaching. It increases the program available for student development teaching strategies and programs, Lancaster, \& Lundberg [27]. Students are engaged in their module materials of teaching because they have ownership over their learning. It increases the mobility of the context in the educational setting and challenges in the classroom experiences. It narrates the ethical and critical pedagogy of students' position in competency based-learning traditional and pedagogy structure in the modality of teaching in the new normal access and approach, Lomer, \& Anthony-Okeke [28]. They are empowered because they have control over when, where, and how they learn in their modules. The limited resources have an impact on the students learning in their module designs. It determines the aims and effect of the modules used on the outcome learning of students in the new normal modality of teaching, Rahmawati, Lestari, \& Umam, [29]. Further, it shows that competency based programs promote individualized learning and accommodates a variety of learning styles, making it a truly personalized experience. It compromises and introduces the personalized effort of learning in various academic subjects. It provides direction on competency based-learning initiative, approach in a classroom 
authentic context and experiences, Walkington, \& Bernacki, [30].

In addition, affordability competency basedlearning shows that the cost of competency based program varies by the different educational institutions program and student paces. It attempts to introduce the framework of competency based-learning in the improved intended outcome in support to the skills and learning development. It offers innovation in refining the competency based-learning development in piloting the measure and analysis of the students' potentials to improve the quality of education in the new normal modality of teaching, Dauphinee, Boulet, \& Norcini [31]. The school, college, or university created competency based programs precisely as a strategy to increase learning. It intricates the rapid global quality of teaching in the advanced technology on the responsibility and challenges of competency basedlearning and quality education in the new normal modality of teaching especially on the development curriculum in the educational setting. Competency based-learning curriculum provides details on the concept that needs to be addressed, Mulenga, \& Kabombwe, [32]. It is free education competency based learning for students to complete their subject and degree. It is a program mandated by the government to fund and improve the educational system in the Philippines. It focuses on the curriculum on competency based-learning knowledge and development in the new normal modality of teaching, Vesikivi, Lakkala, Holvikivi, \& Muukkonen, [33]. It provides the learners progress in their module subjects through the materials provided in their learning enhancement. It brings considerable learning analysis in the new normal online modality of teaching in the use of advanced technology and increased digital support in education. It improves the curriculum to support the learners in the enhanced learning experiences that provides learners' benefits in the educational setting, Troussas, Krouska, \& Virvou [34].

Lastly, the skills-based competency basedlearning and quality education shows that it is a skill based competency based program center that benefits the learners in the new normal on real world competency development. It is a self-directed competence of fundamental learning in the new normal modality of teaching as to learning concept, benefits, and learning process outcome. It develops individual concern on the learning epistemology, constructivist, pragmatic philosophy and humanistic philosophy consideration of the learners in the formal educational setting, Morris [35]. Programs are designed around competencies that are needed for a particular career ensuring that materials provided in the modules are relevant because it identifies the evaluation, assessment, course design, and facilitation practices in an online perspective. It focuses on the online modality of teaching, framework, concept, and development in competency based-learning in a systematic online teaching and instruction, based on the needs of the students to be effective in online classes, standard, best practice, and competency, Martin, Ritzhaupt, Kumar, \& Budhrani, [36]. On the other hand, competency basedprogram outcome is that students are workplace ready and have expertise in their chosen fields. It develops a competency based-learning assessment that requires a program to measure and plan the process for successful implementation of new normal modality teaching to support the principles and implementation of a sustainable transformation in the educational setting. It is a flexible and systematic approach in the potential engagement to promote learning and addresses changes in the sustained competency based learning, Bray, Bradley, Martindale, \& Gusic, [37]. Competency basedprogram is a direct path to a successful career of student's competency graduates. It assesses the outcome of a competency based-learning program that focuses on the job related to the learners in a positive impact on the program of students in their degree of completion, Navarre Cleary [38-40].

\section{CONCLUSION}

1. It shows that competency based-learning and programs are very flexible as to structure depending on the individual learners because students are guided in their learning process and control when and where they complete projects and assessments.

2. Self-paced competency based-learning shows that students feel they can prove mastery, they can take an assessment, receive credit and start on their learning process.

3. Engagement competency based-learning shows that learners are empowered because they have control over when, where, and how they learn in their modules.

4. Affordability competency based-learning shows that it is free education for students to complete their subject and degree.

5. Skills-based competency-based learning shows that programs are focused and centered to the benefits of the learners in the new normal on real world competency development.

\section{RECOMMENDATION}

1. Flexibility competency based-learning programs must follow the educational policy in the new normal classes and modality of teaching because the program is flexible based on the needs of students to enter at any level where the learners are given credits.

2. Self-paced competency based-learning program of education must focus on the final outcome of the learning process of students in the new normal classes since students are able 
to control their pacing because they are not confined by a set learning process.

3. Engagement competency based-learning programs must promote individualized learning and accommodates a variety of learning styles, making it a truly personalized experience in the new normal modality of teaching.

4. Affordability competency based-learning program must provide the learners progress in their module subjects through the material provided in their learning enhancement.

5. Skills-based competency programs must be a direct path to a successful career of students competency graduates based on the needs of the community to where they can apply their learning knowledge and skills in their future jobs.

\section{REFERENCES}

1. Goldhamer, M. E. J., Pusic, M. V., Co, J. P. T., \& Weinstein, D. F. (2020). Can covid catalyze an educational transformation? competency-based advancement in a crisis. New England Journal of Medicine, 383(11), 1003-1005.

2. Hsiao, C. T., Chou, F. C., Hsieh, C. C., Chang, L. C., \& Hsu, C. M. (2020). Developing a competency-based learning and assessment system for residency training: analysis study of user requirements and acceptance. Journal of medical Internet research, 22(4), e15655.

3. Gallardo, K. (2020). Competency-Based Assessment and the Use of Performance-Based Evaluation Rubrics in Higher Education: Challenges towards the Next Decade. Problems of Education in the 21st Century, 78(1), 61-79.

4. Anderson, L. (2018). Competency-based education: Recent policy trends. The Journal of CompetencyBased Education, 3(1), e01057.

5. Wang, H., Tlili, A., Lehman, J. D., Lu, H., \& Huang, R. (2021). Investigating feedback implemented by instructors to support online competency-based learning (CBL): a multiple case study. International Journal of Educational Technology in Higher Education, 18(1), 1-21.

6. Tsai, C. W. (2020). Applying online competencybased learning and design-based learning to enhance the development of students' skills in using PowerPoint and Word, self-directed learning readiness, and experience of online learning. Universal Access in the Information Society, 19(2), 283-294.

7. Sargeant, J., Wong, B. M., \& Campbell, C. M. (2018). CPD of the future: a partnership between quality improvement and competency-based education. Medical education, 52(1), 125-135.

8. Chernikova, O., Heitzmann, N., Stadler, M., Holzberger, D., Seidel, T., \& Fischer, F. (2020). Simulation-based learning in higher education: $A$ meta-analysis. Review of Educational Research, 90(4), 499-541.

9. Egbert, J. L., \& Shahrokini, S. A. (2019). Balancing Old and New: Integrating CompetencyBased Learning into CALL Teacher Education. JALT CALL Journal, 15(1), 3-18.

10. McGaghie, W. C., \& Harris, I. B. (2018). Learning theory foundations of simulation-based mastery learning. Simulation in Healthcare, 13(3S), S15S20.

11. Wood, R. (2019). Students' motivation to engage with science learning activities through the lens of self-determination theory: Results from a singlecase school-based study. Eurasia Journal of Mathematics, Science and Technology Education, 15(7), em1718.

12. Froehlich, D. E., Van Waes, S., \& Schäfer, H. (2020). Linking quantitative and qualitative network approaches: a review of mixed methods social network analysis in education research. Review of Research in Education, 44(1), 244-268.

13. Mays, N., \& Pope, C. (2020). Quality in qualitative research. Qualitative research in health care, 211233.

14. Rahman, M. S. (2020). The advantages and disadvantages of using qualitative and quantitative approaches and methods in language "testing and assessment" research: A literature review.

15. Klar, S., \& Leeper, T. J. (2019). Identities and intersectionality: a case for Purposive sampling in Survey-Experimental research. Experimental Methods in Survey Research: Techniques that Combine Random Sampling with Random Assignment, 419-433.

16. Soviany, P., Ionescu, R. T., Rota, P., \& Sebe, N. (2021). Curriculum self-paced learning for crossdomain object detection. Computer Vision and Image Understanding, 204, 103166.

17. Daumiller, M., Rinas, R., Olden, D., \& Dresel, M. (2021). Academics' motivations in professional training courses: effects on learning engagement and learning gains. International Journal for Academic Development, 26(1), 7-23.

18. Gazi, Y., Baker, N., \& Sibley, K. (2021). Learning at-Scale, Affordability, and Access in a PostCOVID19 World. Georgia Institute of Technology.

19. Kitto, K., Sarathy, N., Gromov, A., Liu, M., Musial, K., \& Shum, S. B. (2020, March). Towards skills-based curriculum analytics: can we automate the recognition of prior learning?. In Proceedings of the Tenth International Conference on Learning Analytics \& Knowledge (pp. 171-180).

20. Markey, K., \& Okantey, C. (2019). Nurturing cultural competence in nurse education through a values-based learning approach. Nurse education in practice, 38, 153-156.

21. Dragoo, A., \& Barrows, R. (2016). Implementing competency-based education: Challenges, strategies, and a decision-making framework. The 
Journal of Continuing Higher Education, 64(2), 73-83.

22. Mallillin, L. L. D., Mallillin, J. B., Carag, E. A., Collado, J. B., \& Largo, M. G. D. (2020). A framework in the online learning process: a guide to educational teaching during covid 19 pandemic. European Journal of Open Education and Elearning Studies, 5(2).

23. O’Neill, T. A., Pezer, L., Solis, L., Larson, N., Maynard, N., Dolphin, G. R., ... \& Li, S. (2020). Team dynamics feedback for post-secondary student learning teams: introducing the "Bare CARE" assessment and report. Assessment \& Evaluation in Higher Education, 45(8), 1121-1135.

24. Wood, R., \& Shirazi, S. (2020). A systematic review of audience response systems for teaching and learning in higher education: The student experience. Computers \& Education, 103896.

25. Vanslambrouck, S., Zhu, C., Pynoo, B., Thomas, V., Lombaerts, K., \& Tondeur, J. (2019). An indepth analysis of adult students in blended environments: Do they regulate their learning in an 'old school way?. Computers \& Education, 128, 75-87.

26. Blau, I., Shamir-Inbal, T., \& Avdiel, O. (2020). How does the pedagogical design of a technologyenhanced collaborative academic course promote digital literacies, self-regulation, and perceived learning of students?. The internet and higher education, 45, 100722.

27. Lancaster, J. R., \& Lundberg, C. A. (2019). The influence of classroom engagement on community college student learning: A quantitative analysis of effective faculty practices. Community College Review, 47(2), 136-158.

28. Lomer, S., \& Anthony-Okeke, L. (2019). Ethically engaging international students: student generated material in an active blended learning model. Teaching in Higher Education, 24(5), 613-632.

29. Rahmawati, R., Lestari, F., \& Umam, R. (2019). Analysis of the effectiveness of learning in the use of learning modules against student learning outcomes. Desimal: Jurnal Matematika, 2(3), 233240.

30. Walkington, C., \& Bernacki, M. L. (2020). Appraising research on personalized learning: Definitions, theoretical alignment, advancements, and future directions.
31. Dauphinee, W. D., Boulet, J. R., \& Norcini, J. J. (2019). Considerations that will determine if competency-based assessment is a sustainable innovation. Advances in Health Sciences Education, 24(2), 413-421.

32. Mulenga, I. M., \& Kabombwe, Y. M. (2019). Understanding a competency-based curriculum and education: The Zambian perspective.

33. Vesikivi, P., Lakkala, M., Holvikivi, J., \& Muukkonen, H. (2020). The impact of projectbased learning curriculum on first-year retention, study experiences, and knowledge work competence. Research Papers in Education, 35(1), 64-81.

34. Troussas, C., Krouska, A., \& Virvou, M. (2020). Using a multi module model for learning analytics to predict learners' cognitive states and provide tailored learning pathways and assessment. In Machine Learning Paradigms (pp. 9-22). Springer, Cham.

35. Morris, T. H. (2019). Self-directed learning: A fundamental competence in a rapidly changing world. International Review of Education, 65(4), 633-653.

36. Martin, F., Ritzhaupt, A., Kumar, S., \& Budhrani, K. (2019). Award-winning faculty online teaching practices: Course design, assessment and evaluation, and facilitation. The Internet and Higher Education, 42, 34-43.

37. Bray, M. J., Bradley, E. B., Martindale, J. R., \& Gusic, M. E. (2020). Implementing Systematic Faculty Development to Support an EPA-Based Program of Assessment: Strategies, Outcomes and Lessons Learned. Teaching and Learning in Medicine, 1-31.

38. Navarre Cleary, M. (2020). Comparing goals to outcomes for graduates of a competency-based education program. The Journal of CompetencyBased Education, 5(4), e01223.

39. Chod, J., Markakis, M. G., \& Trichakis, N. (2021). On the learning benefits of resource flexibility. Management Science.

40. Mallillin, L. L. D., Carag, E. A., Mallillin, J. B., \& Laurel, R. D. (2020). Integration of knowledge through online classes in the learning enhancement of students. European Journal of Open Education and E-learning Studies, 5(1).

Cite This Article: Leovigildo Lito D. Mallillin et al (2021). Competency Based-Learning and Quality Education in the New Normal Modality of Teaching. East African Scholars J Edu Humanit Lit, 4(4), 156-166. 